\title{
Surface Antigens of Intact Aspergillus fumigatus Mycelium: their Localization Using Radiolabelled Protein A as Marker
}

\author{
By VERONICA M. HEARN \\ Mycological Reference Laboratory, London School of Hygiene and Tropical Medicine, \\ Keppel Street, London WCIE 7HT, UK
}

(Received 14 September 1983; revised 10 November 1983)

\begin{abstract}
Isotopically-labelled Protein A from Staphylococcus aureus was used as a marker to quantify binding of IgG molecules to surface antigens of Aspergillus fumigatus mycelium. The IgG class antibodies were obtained from rabbits inoculated with mycelial fractions and from patients suffering from aspergillosis and aspergillus-related diseases. The highest incorporation of label was obtained with an antiserum from rabbits inoculated with $A$. fumigatus wall material. Antibodies raised to other antigenic fractions of $A$. fumigatus and antibodies from patients infected with aspergillus gave lower levels of incorporation of Protein A. In competitive binding experiments, pre-incubation of antibodies with partially purified aspergillus antigens depressed subsequent binding to the mycelial surface by $20-30 \%$ of that of the control values. Low molecular weight disaccharides and oligosaccharides were without effect in this system. Preincubation of $A$. fumigatus with lectins having specificities for defined sugar residues did not reduce subsequent antigen/antibody interaction. Treatment of the mycelial surface with certain proteolytic or polysaccharolytic enzymes led to a decrease in antibody binding, while pretreatment of $A$. fumigatus with the hydrolytic enzyme mixture of Trichoderma harzianum culture filtrate gave increased antibody binding. Aspergillus species showed different susceptibilities to enzyme action and their surface structures could be differentiated from $A$. fumigatus on this basis. These differences were not obvious in direct binding experiments where antibodies raised to A. fumigatus wall bound with equal facility to antigenic sites located on the walls of other Aspergillus species.
\end{abstract}

\section{INTRODUCTION}

Fungal polysaccharides located in the outer layer of the cell wall are usually covalently bound to form peptido-polysaccharide complexes (Lloyd, 1970; Ballou, 1976). These are the cell wall components primarily responsible for reactions with antibodies (Lloyd \& Bitoon, 1971) and lectins such as concanavalin A (Travassos et al., 1977). Lloyd et al. (1978) used immunofluorescence with specific rabbit antisera to determine the distribution of antigenic polysaccharides on the surface of the different cell types of Sporothrix schenckii. Other studies have been based on the action of lytic enzymes. Thus, Previato et al. (1979) found that treatment of isolated walls of $S$. schenckii with a $(1 \rightarrow 3)-\beta$-exo,endo-glucanase resulted in a general disorganization of the skeletal, glucan-rich layer, and Sunayama \& Suzuki (1970) destroyed the precipitating ability of mannan of Saccharomyces cerevisiae with an $\alpha$-mannosidase from Arthrobacter. Sequential enzyme treatment has been used to obtain information concerning polymer distribution in the cell walls of Neurospora, Schizophyllum and Phytophthora (Hunsley \& Burnett, 1970) and to release antigens from the cell walls of Histoplasma (Reiss, 1977). Evidence for a layered arrangement of hyphal cell walls was provided by the finding that treatment of Neurospora crassa with an exo-( $(1 \rightarrow 3)$ - $\beta$-glucanase followed by chitinase yielded $N$-acetylglucosamine residues while chitinase alone released very little free hexosamine (Potgieter \& Alexander,

Abbreviations: ConA, concanavalin A; SpA, staphylococcal Protein A; SEM, scanning electron microscopy. 
1965). A similar pattern has been described for Aspergillus oryzae (Horikoshi \& Arima, 1962) and for A. nidulans (Bull, 1970). With fluorescein-conjugated lectins as probes, Stoddart \& Herbertson (1978) reported strong hyphal staining in tissue sections of $A$. fumigatus incubated with lectins specific for $N$-acetylgalactosamine and $\beta$-D-galactose, and moderate staining with one specific for $\alpha$-D-glucose and $\alpha$-D-mannose residues.

Galactomannan, glucan and glycoprotein structures with antigenic activity have been isolated from $A$. fumigatus mycelium (Azuma et al., 1969). Little is known about the location in the organism of these and other antigenic residues and their accessibility to immunoglobulin molecules. In this study, antibodies raised to partially purified antigenic fractions of $A$. fumigatus were used in an attempt to obtain information concerning surface structures accessible for direct binding to specific IgG molecules. This has been measured by uptake of [ $\left.{ }^{125} \mathrm{I}\right]$ Protein A (SpA), a technique which has been widely used for the detection of cell surface antigens (Dorval et al., 1974; Biberfeld et al., 1975; Zeltzer \& Seeger, 1977). Aspergillus belongs to the chitin-glucan group of fungi (Bartnicki-Garcia, 1968) with galactomannan as a minor constituent. Therefore, saccharides with related structures and lectins with specificities for these sugars were used as probes in competitive-binding experiments to try and elucidate the nature of the binding sites. In addition, hydrolases, which included a variety of glucanases, mannosidases and chitinase, were tested for their ability to disrupt surface interactions.

A preliminary report on some of this work has appeared elsewhere (Hearn et al., 1981).

\section{METHODS}

Preparation of mycelial pellets. The following species of Aspergillus were used (accession numbers are for the National Collection of Pathogenic Fungi): A. fumigatus NCPF 2109, A. flavus NCPF 2008, A. terreus NCPF 2026, $A$. niger NCPF 2022 and $A$. nidulans NCPF 2020. Neutral glucose/peptone medium (100 ml) supplemented with $0.2 \%(\mathrm{w} / \mathrm{v})$ yeast extract and $0 \cdot 5 \%(\mathrm{w} / \mathrm{v})$ Righelato's salt solution (Righelato et al., 1968) was inoculated with $2 \times 10^{6}$ spores of each Aspergillus species. The organisms were grown for approximately $40 \mathrm{~h}$ at $30^{\circ} \mathrm{C}$ in a Gallenkamp orbital shaker incubator at 100 r.p.m. Mycelia were harvested in the form of compact spheres $2-2.5 \mathrm{~mm}$ diameter, the culture medium being removed by filtration through nylon membranes. The size of the pellets was such that they could be taken up on the tip of a Pasteur pipette while being too large to penetrate into it. Mycelial pellets were washed in $0.01 \mathrm{M}-\mathrm{PBS}$ at $\mathrm{pH} 7.4$ containing $4 \mathrm{mM}-\mathrm{Na}_{2}$ EDTA, before distribution in disposable test tubes (type LP3 from Luckham, Burgess Hill, Sussex, UK) at 4 pellets per tube.

Preparation of antigens. A $3 \mathrm{~d}$ preparation of $\boldsymbol{A}$. fumigatus mycelium grown in neutral glucose/peptone medium at $30{ }^{\circ} \mathrm{C}$ was harvested by filtration, and the resultant mycelial mat was washed with water until the washings were clear (Proctor, 1976). Rupture of the organisms was achieved using a Dynomill cell disintegrator (Glen Creston, London, UK) at $4{ }^{\circ} \mathrm{C}$; after centrifugation, the insoluble pellet was put aside and used as a source of wall material. The supernatant was concentrated by counter-dialysis against a $10 \%(w / v)$ aqueous solution of PEG 6000; this constituted the total water-soluble material of the mycelium (Hearn \& Mackenzie, 1979).

Antigenic fractions were obtained by salt precipitation in a two-step process whereby the water-soluble material was saturated with solid ammonium sulphate at room temperature to give a precipitate which was collected. The ammonium sulphate-soluble supernatant fraction produced at this stage was also retained. After redissolving the solid ammonium sulphate fraction in water, both fractions were exhaustively dialysed against water, and any insoluble residue was removed by centrifugation. The soluble supernates were concentrated to a suitable volume by counter-dialysis against PEG 6000 and stored at $-20^{\circ} \mathrm{C}$.

Additional antigenic fractions were separated from water-soluble material of $A$. fumigatus on the basis of their attachment or non-attachment to concanavalin A (ConA). A column of ConA Sepharose (Pharmacia) was equilibrated with $1 \mathrm{mM}$-Tris/ $\mathrm{HCl}$ buffer, $\mathrm{pH} 7 \cdot 2$, containing $1 \mathrm{~mm}-\mathrm{CaCl}_{2}, 1 \mathrm{~mm}-\mathrm{MnCl}_{2}$ and $0 \cdot 25 \mathrm{M}-\mathrm{NaCl}$. The water-soluble material in the same buffer was applied to the column surface. Elution was effected in the same buffer at $4{ }^{\circ} \mathrm{C}$ and resulted in the elution with the void volume of protein-rich material. Subsequent application of $0.2 \mathrm{M}$-methyl $\alpha$-D-mannopyranoside in $1 \mathrm{mM}$-Tris/ $\mathrm{HCl}$ buffer resulted in the elution of carbohydrate-rich material which had been bound to ConA (Wilson \& Hearn, 1983). The relevant column fractions were pooled, dialysed and concentrated to a suitable volume against PEG 6000 and stored at $-20{ }^{\circ} \mathrm{C}$.

Cytoplasmic antigens, free of cell wall components, were prepared as protoplasts obtained by controlled enzymic lysis of an $18 \mathrm{~h}$ culture of $A$. fumigatus mycelium (Hearn et al., 1980). The protoplasts were separated from the growth medium by filtration and washing and were stored at $-20^{\circ} \mathrm{C}$.

The insoluble residue obtained during the preparation of the water-soluble material was washed repeatedly in hot water $\left(50-60^{\circ} \mathrm{C}\right)$ until the washings were clear. While some material, including labile components, is lost by this process, the requirement was for cell wall material free from cytoplasmic and nuclear contaminants (Hearn \& 
Mackenzie, 1979). The pellet was dried to constant weight over $\mathrm{P}_{2} \mathrm{O}_{5}$ and stored at $-20^{\circ} \mathrm{C}$. This constituted crude, unextracted cell wall material.

Production of antisera. Antibodies were produced in New Zealand White rabbits. For predominantly carbohydrate antigens (cell wall and carbohydrate-rich fraction) the following protocol was used. Antigen (10 mg dry weight) was mixed with an equal volume of Freund's complete adjuvant and injected intramuscularly into a buttock. Ten days later the same amount of antigen was mixed with an equal volume of Freund's incomplete adjuvant and injected into the other buttock. Ten days later the same level of antigen with Freund's incomplete adjuvant was injected into several subcutaneous sites. Ten days later $5 \mathrm{mg}$ antigen was given intravenously without adjuvant. One week later the animal was test-bled. Sometimes another intravenous injection was required to obtain a serum of adequate titre.

The protocol used for protein-enriched antigens (cytoplasm and protein-rich fraction) was as follows. Antigen ( $0.5 \mathrm{mg}$ dry weight) was mixed with an equal volume of Freund's complete adjuvant and injected intramuscularly into a buttock. Ten days later a similar injection was made into the other buttock. The rabbits were left for five months and then inoculated subcutaneously in many sites with $0.5 \mathrm{mg}$ antigen mixed with Freund's incomplete adjuvant. After ten days the animals were given $0.1 \mathrm{mg}$ antigen intravenously without adjuvant. A test-bleed was taken ten days later. Sometimes an additional intravenous injection was required.

Antiserum to the total water-soluble material from ruptured mycelium was obtained as previously described (Hearn \& Mackenzie, 1980).

An antiserum (SBS) raised to a mixture of mycelial and culture filtrate antigens of $A$. fumigatus was a generous gift from Dr K. Holmberg of the State Bacteriology Laboratory, Stockholm, Sweden.

An antiserum (X-9) raised to an alkali extract (Lehmann \& Reiss, 1978) of $A$. fumigatus mycelium was a generous gift from Dr E. Reiss of the Center for Disease Control, Atlanta, Georgia, USA.

Serum was collected from rabbits prior to injection of antigens for use as a negative control.

Human sera. Sera were obtained from patients fulfilling the diagnostic criteria for aspergillosis. Some were specimens received by our laboratory, while the remainder were kindly donated by Dr J. Edwards of Sully Hospital, Glamorgan, UK. Three serum pools were prepared, numbered human pool 1, 2 and 3; all were highly reactive in serological tests. Serum from subjects negative for specific IgG by an enzyme-linked immunosorbent assay (Wilson \& Hearn, 1983), was also collected for use as a negative control.

Preparation of an $\mathrm{Ig} G$ fraction. The bulk of the plasma proteins were precipitated with caprylic acid (Steinbuch \& Audran, 1969). The IgG component (and a portion of the IgA) which remained in the supernatant was concentrated five-fold. Azide $(0 \cdot 1 \%, \mathrm{w} / \mathrm{v})$ was added as a preservative and the solutions were stored at $4{ }^{\circ} \mathrm{C}$. This procedure was carried out on all test sera.

Radio-iodination of SpA and ConA. The staphylococcal Protein A (SpA) used in these experiments was partiallypurified material prepared from Staphylococcus aureus (Cowan strain) and obtained from Sigma (catalogue no. P9267). Initial experiments were performed using $\mathrm{SpA}$ trace-labelled with the Bolton and Hunter reagent $\mathrm{N}$ succinimidyl 3-(4-hydroxy 5-[ $\left.{ }^{125} \mathrm{I}\right]$ iodo phenyl) propionate (Amersham), essentially as described by Bolton \& Hunter (1973). SpA $(0.05 \mathrm{mg})$ in $0.2 \mathrm{M}$-sodium borate buffer at $\mathrm{pH} 8.5$ was added to $0.5 \mathrm{mCi}(18.5 \mathrm{MBq})$ dried reagent and allowed to react overnight at $4{ }^{\circ} \mathrm{C}$. The $\left[{ }^{125} \mathrm{I}\right] \mathrm{SpA}$ was recovered from a commercially prepared G-25 Sephadex column (Pharmacia) when it eluted in the void volume. It was stored at $-70^{\circ} \mathrm{C}$ in the presence of gelatin; new batches of $\left[{ }^{125} \mathrm{I}\right] \mathrm{SpA}$ were prepared every three weeks. ConA (A grade, from Calbiochem), was similarly labelled by the procedure of Bolton \& Hunter (1973) and stored at $-70^{\circ} \mathrm{C}$. The specific activity of $\left[{ }^{125} \mathrm{I}\right] \mathrm{SpA}$ and $\left[{ }^{125} \mathrm{I}\right] \mathrm{ConA}$ was $10^{4}$ c.p.m. $\mu \mathrm{g}^{-1}$ in each case.

Polysaccharides and oligosaccharides for competitive binding assays. Polysaccharides used for binding to specific A. fumigatus antibodies were soluble starch, laminarin $[(1 \rightarrow 3)-\beta$-D-glucan] which was kindly supplied by $D r F$. Chattaway, formerly of Leeds University, and a $(1 \rightarrow 3)$ - $\alpha$-D-glucan from Polyporus betulinus which was a welcome gift from Dr E. T. Reese (US Army Laboratories, Natick, Mass., USA.). The sugars used in this study were obtained as partial hydrolysis products of polysaccharides from A. fumigatus antigens by Dr P. A. J. Gorin, Prairie Regional Laboratory, Saskatoon, Canada. They included: $\beta$-D-Glc $p-(1 \rightarrow 3)$-D-Glc; $\beta$-D-Glc $p-(1 \rightarrow 3)-\beta$-D-Glc $p$ $(1 \rightarrow 3)$-D-Glc (laminaribiose and laminaritriose, respectively); $\beta$-D-Gal $f$-( $1 \rightarrow 5)$-D-Gal; $\beta$-D-Gal $f$ - $(1 \rightarrow 5)-\beta$-D-Gal $f$ -

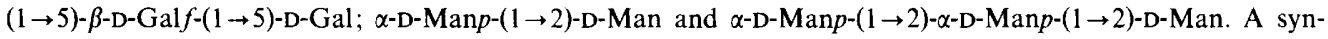
thetic trisaccharide with the structure:

$$
\left.\begin{array}{l}
\beta \text {-D-Glcp-(1 }{ }_{6} \\
\beta \text {-D-Glcp-(1-3 }
\end{array}\right)-\alpha \text {-D-Glc } p-1 \rightarrow \mathrm{OMe}
$$

was a gift from Dr T. Ogawa, Institute of Physical and Chemical Research, Saitana, Japan.

Exposure of mycelial surfaces to hydrolytic enzymes. $\alpha$-Amylase (EC 3.2.1.1) ex Bacillus subtilis, $\beta$-amylase (EC 3.2.1.2) ex barley and pronase ex Streptomyces griseus were purchased from Koch-Light. $\beta$-Galactosidase (EC 3.2.1.23) ex bovine liver, $S$. griseus protease, papain (EC 3.4 .22.2) from papaya latex, chitinase (EC 3.2.1.14) 
ex $S$. griseus (with slight $\beta$-glucanase activity), $\alpha$-mannosidase (EC 3.2.1.24) from jack bean, $\alpha$-chymotrypsin (EC 3.4.21.1) from bovine pancreas and $\beta$-glucosidase (EC 3.2.1.21) from almonds were commercial preparations from Sigma. Trypsin (EC 3.4.21.4) and lytic enzyme $\mathrm{L}_{1}$ from Cytophaga [contains several endo$(1 \rightarrow 3)-\beta$ - and endo-( $1 \rightarrow 4)$ - $\beta$-glucanases] were both from BDH. An exo-( $1 \rightarrow 3)$ - $\beta$-glucanase (Basidiomcete QM806) free of cellulase and $\beta$-glucosidase was from Dr E. T. Reese. A mixture of exo- and endo- $\beta$-mannosidases (from the culture filtrate of a strain of Aeromonas species F-25) was kindly provided by Drs T. Araki and M. Ito, both of the Department of Fisheries, Fukuoka, Japan. Unfractionated culture filtrate from Trichoderma harzianum grown on A. fumigatus, which is capable of hydrolysing a wide range of polysaccharides in addition to proteins, was also tested.

Enzymes were used at a final concentration of $0.4 \%(w / v)$ except for crude lytic enzyme $L_{1}(1 \%$, w/v). The culture filtrate of $T$. harzianum was diluted in acetate buffer at $\mathrm{pH} 5.0$ to the extent where it caused a measurable effect on $A$. fumigatus mycelium without causing total degradation. $\alpha$-Mannosidase solution was used at a $1: 2$ dilution in acetate buffer at $\mathrm{pH} 4 \cdot 5$. The exo-glucanase from Basidiomycete QM806, which has a broad $\mathrm{pH}$ optimum (Dr E. T. Reese, personal communication), was used at $\mathrm{pH} 5.0$ and the mannosidase mixture from Aeromonas was used at pH 6.0, as recommended by Dr T. Araki. Commercial enzyme preparations were used at the $\mathrm{pH}$ specified by the supplier; the buffer concentration in each case was $0.05 \mathrm{M}$. Fungal pellets were routinely incubated for $2 \mathrm{~h}$ in a shaker bath at $37^{\circ} \mathrm{C}$. Chitinase was incubated with $A$. fumigatus for $3 \mathrm{~h}$; a longer time period caused damage to the controls. Although the minimum hydrolysis time with chitinase is considered to be $12 \mathrm{~h}$, this enzyme affected the surface of $\boldsymbol{A}$. fumigatus germ tubes in $30 \mathrm{~min}$ at the same temperature (V. M. Hearn, unpublished results). It should also be noted that the temperature selected was suboptimal for pronase, which has optimal activity at approximately $50^{\circ} \mathrm{C}$.

Lectin-binding experiments. Lectins were used as possible competitive inhibitors of antibody binding to surface carbohydrate antigens of $A$. fumigatus mycelium. ConA, A grade, with specificity for $\alpha$-D-mannopyranose and $\alpha$-Dglucopyranose sugars and closely related structures, was from Calbiochem; Triticum vulgaris lectin (wheat germ agglutinin) and lectins from Ricinus communis (castor bean type I and type II) with specificities for $N$ acetylglucosamine, $\mathrm{N}$-acetylgalactosamine and D-galactose respectively, were from Sigma. ConA was tested at a final concentration of $1.25 \%(w / v)$ in PBS; the other lectins were tested at a final concentration of $0 \cdot 25 \%(w / v)$.

Immunoassay. The radioimmunoassay was carried out as follows. Aspergillus fumigatus, distributed at four mycelial pellets per tube, was washed three times with 0.01 M-PBS containing 4 mM-EDTA, which constituted the wash solution. After each wash, the supernatant was removed by suction, using a Pasteur pipette. The pellets were incubated for $1 \mathrm{~h}$ at room temperature with $200 \mu \mathrm{l}$ bovine serum albumin solution $(5 \%, \mathrm{w} / \mathrm{v})$. This mixture was replaced by $50 \mu \mathrm{lgG}$ ( $\equiv 0.5 \mathrm{mg}$ protein) in PBS and incubated for a further $18 \mathrm{~h}$ at $4{ }^{\circ} \mathrm{C}$. The cells were washed twice, $85 \mu \mathrm{g}\left[{ }^{125} \mathrm{I}\right] \mathrm{SpA}$ in bovine serum albumin $(1 \%, \mathrm{w} / \mathrm{v})$ was added and the mixture was incubated for $30 \mathrm{~min}$ at room temperature. After washing three times the radioactivity bound to pellets was measured in a counter (LKB, 1275 Minigamma). Each assay was done in triplicate. The assay was repeated if the coefficient of variation was $>12 \%$. The protocol is based on that of Dorval et al. (1975).

Competitive binding experiments involved a pre-incubation of $\mathrm{IgG}$ with the appropriate antigen or sugar ( $2 \mathrm{~h}$ at $25^{\circ} \mathrm{C}$ ) before exposing them to the fungal pellets and proceeding as above. The effect of lectins on IgG uptake by mycelium was determined by incubating the specified lectin with the fungal pellets in PBS for $2 \mathrm{~h}$ at room temperature. The pellets were washed three times before incubating with $\mathrm{IgG}$ and proceeding as above.

Scanning electron microscopy $(S E M)$. Fungal pellets were fixed in $3 \%(\mathrm{w} / \mathrm{v})$ glutaraldehyde (at $\mathrm{pH} 7.4$ in cacodylate buffer) and osmium tetroxide, dehydrated through acetone and critical-point dried. They were mounted on aluminium stubs, sputter-coated with gold and examined in a Jeol JSM25 scanning electron microscope.

\section{RESULTS}

\section{Experimental procedure}

Preliminary experiments were required in order to obtain optimal reaction conditions together with minimal background readings. An IgG fraction gave less non-specific attachment to the mycelial pellets than did whole serum; this may have been due to surface binding of IgM and IgA, which can sometimes interact with SpA (Harboe \& Fölling, 1974). A mild fixation step with paraformaldehyde after antibody binding, in order to prevent spontaneous dissociation of the antigen-antibody complexes (Biberfeld et al., 1974), was omitted when it was found that the increase seen with aspergillus-positive sera was accompanied by a corresponding increase with negative sera. A proportion of [ $\left.{ }^{125} \mathrm{I}\right] \mathrm{SpA}$ bound directly to mycelial pellets (see Table 1) but it was preferred to labelled immunoglobulin which led to a twofold increase in non-specific attachment to surface structures (cf. Biberfeld et al., 1975). 


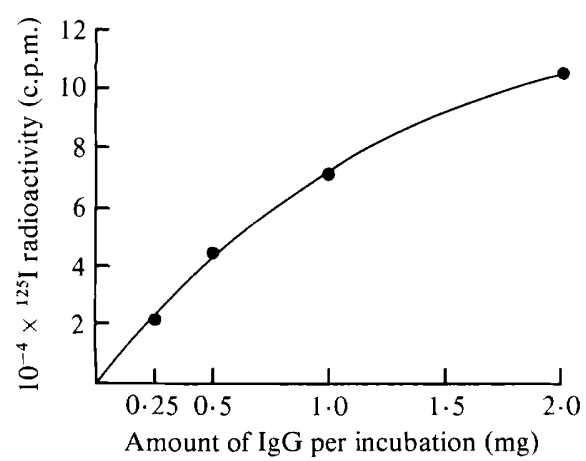

Fig. 1

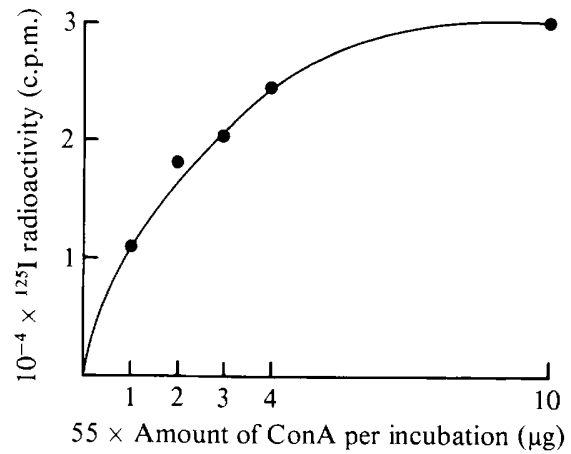

Fig. 2

Fig. 1. Proportional increase in [ $\left.{ }^{125} \mathrm{I}\right]$ Protein A (SpA) uptake by $A$. fumigatus mycelial pellets relative to the concentration of specific IgG in the incubation mixture. An IgG fraction produced in rabbits to Aspergillus wall material was used.

Fig. 2. Measurement of direct binding of $\left[{ }^{125} \mathrm{I}\right] \mathrm{ConA}$ to the mycelial surface of $A$. fumigatus. For conditions of incubation see Methods.

Table 1. Comparison of uptake by A. fumigatus mycelial pellets of $\operatorname{IgG}$ from rabbit and human sources

\begin{tabular}{lc}
\multicolumn{2}{c}{ Rabbit } \\
$\begin{array}{lc}\text { IgG* raised to } \\
\text { specified antigens }\end{array}$ & $\begin{array}{c}\text { Percentage } \\
\text { binding } \dagger\end{array}$ \\
Wall & 100 \\
Cytoplasm & $29 \cdot 0 \pm 9 \cdot 3$ \\
Water-soluble & $45 \cdot 0 \pm 7 \cdot 3$ \\
Protein-rich & $37 \cdot 7 \pm 15 \cdot 5$ \\
Carbohydrate-rich & $34 \cdot 5 \pm 10 \cdot 3$ \\
Mycelial/filtrate (SBS) & $45 \cdot 5 \pm 10 \cdot 3$ \\
Alkali extract (X-9) & $50 \cdot 5 \pm 4 \cdot 9$ \\
Rabbit negative & $19 \cdot 4 \pm 2 \cdot 5$ \\
\multicolumn{1}{c}{-} & $10 \cdot 6 \pm 4 \cdot 1$
\end{tabular}

$\begin{array}{lc}\begin{array}{c}\text { IgG from patients } \\ \text { with aspergillosis }\end{array} & \begin{array}{c}\text { Percentage } \\ \text { binding } \dagger\end{array} \\ \text { Human pool 1 } & 63 \cdot 0 \pm 21 \cdot 8 \\ \text { Human pool 2 } & 48 \cdot 0 \pm 12 \cdot 4 \\ \text { Human pool 3 } & 94 \cdot 3 \pm 5 \cdot 2 \\ \text { Human negative } & 20 \cdot 6 \pm 7 \cdot 4\end{array}$

* For details of IgG fractions see Methods.

$\dagger$ Binding of wall IgG to surface receptors is expressed as $100 \%$.

The mean value for 12 experiments was 31019 c.p.m. \pm 6359 c.p.m. (i.e. coefficient of variation $=20 \cdot 5 \%$ ). Other IgG values represent the mean of at least three experiments \pm SD. Results with human sera are given relative to the rabbit wall fraction.

Initial experiments were done with $\mathrm{SpA}$ labelled with the Bolton \& Hunter reagent. No detectable differences were apparent when the chloramine-T protocol for iodination was investigated (Hunter \& Greenwood, 1962), and parallel experiments with SpA labelled by the two procedures were analysed. Either a $90 \mathrm{~min}$ incubation with antibody at $25{ }^{\circ} \mathrm{C}$ or an overnight incubation at $4{ }^{\circ} \mathrm{C}$ proved satisfactory while periods $>30 \mathrm{~min}$ did not increase uptake of $\mathrm{SpA}$. SpA was added in excess of antibody in order to quantify binding of the latter to cellular sites. The supplier's instructions were followed in this case. The amount of [ $\left.{ }^{125} \mathrm{I}\right] \mathrm{SpA}$ bound to the mycelial pellets was directly proportional to the amount of antibody taken up by the cellular surface (Fig. 1). The uptake of specific IgG relative to the total IgG started to plateau at a concentration of $2 \mathrm{mg}$ protein per 4 pellets.

A comparison was made of the ability of IgG from different sources to bind to receptor sites on the mycelial surface (Table 1). Highest uptake was seen with the IgG fraction prepared from antiserum raised to crude wall material while an antiserum raised to cytoplasmic components showed binding only $10 \%$ above that given by negative control sera. Sera raised to antigenic fractions gave intermediate values, as did antiserum raised to a water-soluble mycelial 


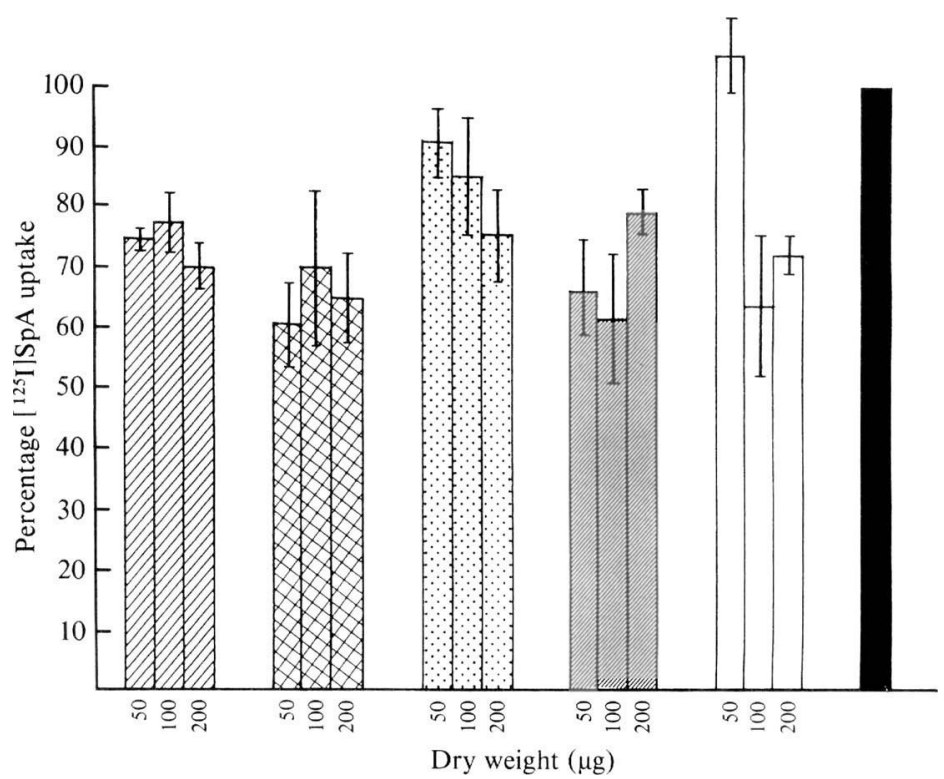

Fig. 3. Inhibition of antibody binding to $A$. fumigatus by pre-incubation of the mycelium with antigenic fractions. For conditions of incubation see Methods. Fractions: $\square$, water-soluble; $\oslash$, protein-rich; $\square$, carbohydrate-rich; , protein-rich, ammonium sulphate-insoluble; $\square$, carbohydrate-rich, ammonium sulphate-soluble; control (no antigen). The bars represent SD.

preparation, and one raised to a mixture of mycelial and culture filtrate antigens. An antiserum raised to an alkali-soluble extract of $\boldsymbol{A}$. fumigatus and considered to be directed mainly against galactomannan and $(1 \rightarrow 3)-\alpha$-D-glucan moieties (by analogy with extracts prepared from $A$. nidulans and $A$. niger: Bull, 1970; Bardalaye \& Nordin, 1977) was also in this category. Human sera showed variable binding capacities to surface structures, indicating qualitative differences in their $\operatorname{IgG}$ fractions.

\section{Effects of lectins on IgG uptake}

Blocking of receptor sites by pre-treatment of the mycelium with lectins with primary specificities for $D$-hexose and hexosamine residues was attempted. All lectins were ineffective at the concentrations tested. The extent to which ConA bound to non-antigenic sites on the mycelial surface was investigated by the use of $\left[{ }^{125} \mathrm{I}\right]$ ConA, following a $2 \mathrm{~h}$ incubation at room temperature (Fig. 2).

\section{Competitive binding experiments with antigenic fractions}

A number of soluble antigens were examined for their ability to block the binding of specific IgG to cell-bound antigens. Two of the antigens used effected $>20 \%$ inhibition and one $>30 \%$ inhibition of cellular binding at a concentration of $50 \mu \mathrm{g}$ dry wt per incubation. Increased inhibition was not seen with higher concentrations of these antigens. The predominantly carbohydrate antigens had to be used at $100 \mu \mathrm{g}$ (ammonium sulphate-soluble) and $200 \mu \mathrm{g}$ (carbohydrate-rich) per incubation to achieve this degree of inhibition to the system (Fig. 3). Pure polysaccharides, low molecular weight oligosaccharides and disaccharides, as specified in Methods, were without effect at $200 \mu \mathrm{g}$ dry wt per incubation. Higher concentrations of sugars were not examined.

\section{Effect of enzymes on surface interactions}

An enzyme effect was considered significant if uptake of [ ${ }^{125}$ I $] \mathrm{SpA}$ varied by $>20 \%$ of the control values. On that basis, pronase, papain, trypsin and chymotrypsin were without effect 
Table 2. Effect of polysaccharidases on antibody binding to Aspergillus mycelial surfaces

Results are expressed as percentage binding of antibody relative to control values. Hydrolytic enzyme control, $\beta$-mannosidase, gave a mean binding value of $93 \% \pm 4 \cdot 2$. NS, Not significant (set at an arbitrary value of $100 \pm 20 \%$ with a permissible coefficient of variation among replicates of $10 \%$; dis, mycelial disintegration.

$\begin{array}{lccccccc} & \begin{array}{c}\text { T. harzianum } \\ \text { culture }\end{array} & \begin{array}{c}\text { Cytophaga } \\ \text { lytic } \\ \text { Siltrate }\end{array} & \begin{array}{c}\text { Exo- }(1 \rightarrow 3) \\ \text { enzyme }\end{array} & \beta \text {-glucanase } & \alpha \text {-Amylase } & \beta \text {-Amylase } & \alpha \text {-Mannosidase Chitinase } \\ \text { A. fumigatus } & 121 & 75 & \text { NS } & 65 & \text { NS } & 75 & \text { NS } \\ \text { A. flavus } & \text { NS } & \text { NS } & 134 & 67 & \text { NS } & \text { NS } & \text { NS } \\ \text { A. } \text { terreus } & 77 & \text { dis } & \text { NS } & \text { NS } & 55 & 57 & 124 \\ \text { A. niger } & \text { NS } & \text { dis } & \text { NS } & 64 & \text { NS } & \text { NS } & 76 \\ \text { A. nidulans } & \text { NS } & 66 & \text { NS } & 62 & 64 & \text { NS } & \text { NS }\end{array}$

while with bacterial protease uptake of SpA was reduced to $77 \%$ of that of the control value. Of the polysaccharidases, only $T$. harzianum culture filtrate, $\alpha$-amylase, $\alpha$-mannosidase and Cytophaga lytic enzyme $\mathrm{L}_{1}$ at $1 \%(\mathrm{w} / \mathrm{v})$ had an effect (at $0.4 \%$, w/v, results with the latter enzyme were not reproducible). A $\beta$-mannosidase was included as a negative control since $\beta$-linked mannose residues are unknown for Aspergillus (Azuma et al., 1971; Bardalaye \& Nordin, 1977). Other Aspergillus spp. were included at this stage for comparative purposes and quite considerable differences in enzyme action were detectable (Table 2). These differences were not apparent in direct binding experiments where an $\mathrm{IgG}$ fraction raised to $A$. fumigatus wall bound with equal facility to the surface of all species tested.

\section{SEM studies}

No differences were apparent in thin sections when $A$. fumigatus pellets treated with Cytophaga lytic enzyme were compared with control samples. An effect was noted when the mycelium was examined by SEM. This effect was much more severe in the cases of $A$. terreus and $A$. niger treated under the same conditions (Fig. 4).

\section{DISCUSSION}

The use of [ $\left.{ }^{125} \mathrm{I}\right] \mathrm{SpA}$ to quantify antibody-binding to $A$. fumigatus mycelium showed a clear distinction between non-immunized and hyperimmunized sera. Major differences in chemical composition between wall and cytoplasm were emphasized, this technique revealing few shared components. Human sera showed variable binding capacity but two of three pools tested had very strong reactivity.

When incubated with $A$. fumigatus soluble antigens ConA caused antigen precipitation and subsequent inhibition of antigen-antibody binding (Hearn \& Mackenzie, 1979). The fact that binding of ConA to the mycelial surface occurred without causing a reduction in antibody uptake indicated that the sites of greatest affinity for the lectin are not the antigenic sites. Other lectins used here are capable of binding only to residues at the non-reducing terminals of saccharide chains. If a large part of the galactose residues in $A$. fumigatus is in the furanose form, this would preclude its reacting with castor bean lectin.

The effect of enzymes on mycelial surfaces was analysed. It has been shown that walls contain autolysing enzymes but the concentration of sugars released in $2 \mathrm{~h}$ at $37^{\circ} \mathrm{C}$ was low (Polacheck \& Rosenberger, 1975). Odds et al. (1974) found that, despite substantial release of sugars from the cell wall of Histoplasma capsulatum with a mixture of $(1 \rightarrow 3)-\beta$-D-glucanase and chitinase, only a small and probably insignificant change in antigenic titre occurred, as measured by complement fixation tests. I have observed substantial changes in antibody uptake with relatively young cultures containing a low concentration of melanin, which can inhibit enzymic hydrolysis (Kuo \& Alexander, 1967). San-Blas (1982) suggests that $(1 \rightarrow 3)-\alpha$-D-glucan protects young, non-melanized hyphae, presumably because of its ability to hinder hydrolytic enzymes from reaching their substrate. I was unable to inhibit antigen-antibody binding with a $(1 \rightarrow 3)-\alpha-$ 

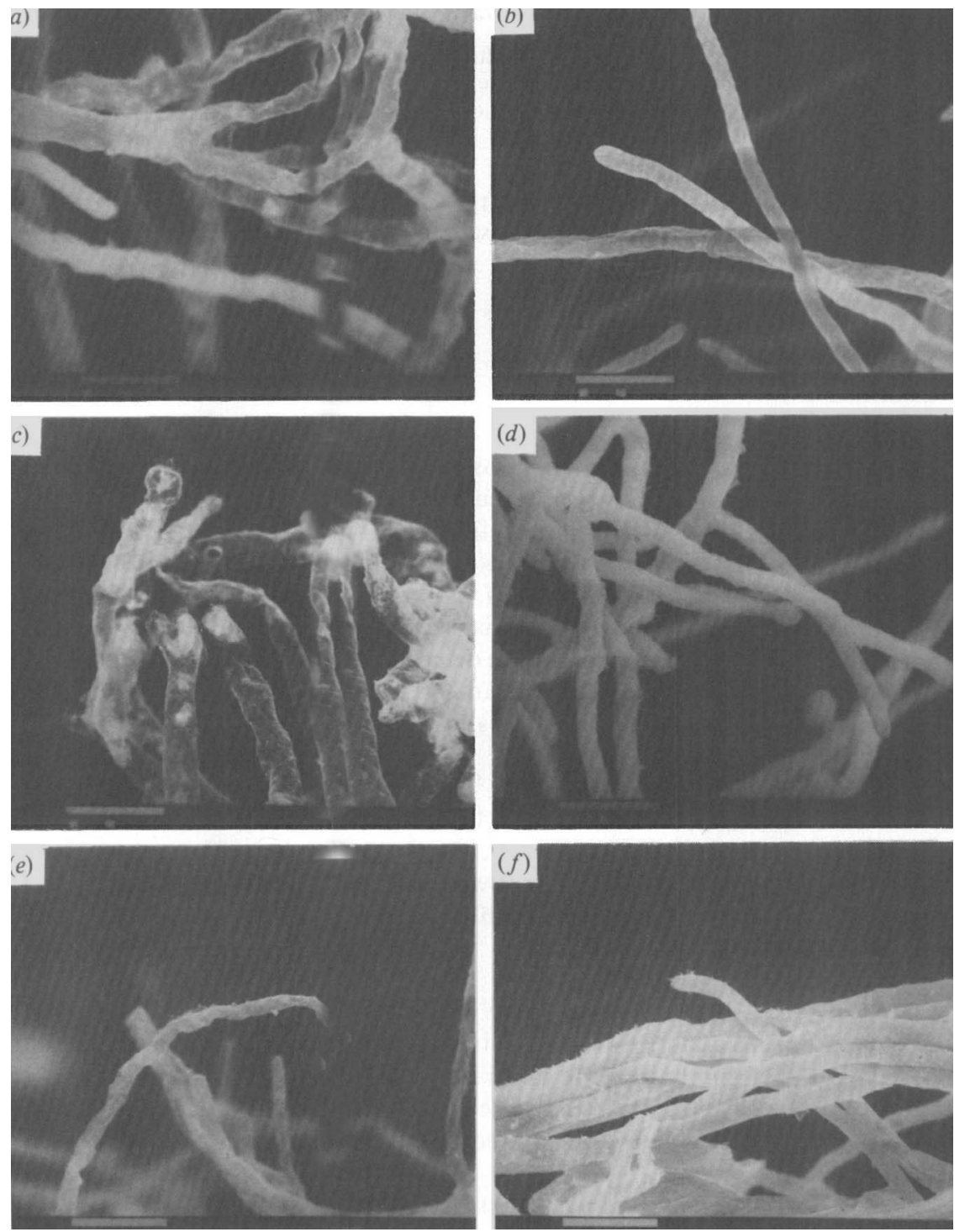

Fig. 4. Scanning electron microscopy of Aspergillus mycelium after enzyme treatment. (a) A. fumigatus incubated with $C y$ tophaga lytic enzyme (for details see Methods); $(b)$ A. fumigatus incubated in the absence of enzyme; (c) A. terreus incubated with $C$ ytophaga enzyme; $(d) A$. terreus incubated in the absence of enzyme; (e) A. niger incubated with Cytophaga enzyme; $(f) A$. niger incubated in the absence of enzyme. The bar markers represent $10 \mu \mathrm{m}$.

D-glucan preparation; however, an antiserum raised to a presumptive galactomannan and $(1 \rightarrow 3)$ - $\alpha$-D-glucan-containing extract showed appreciable binding to fungal pellets.

Studies on $A$. niger and $A$. nidulans have shown a cell wall composed of glucan (40-60\%) and chitin $(10-20 \%)$; the glucans are predominantly alkali-soluble $(1 \rightarrow 3)-\alpha$-linked residues and alkali-resistant $(1 \rightarrow 3)-\beta$ - and $(1 \rightarrow 4)$ - $\alpha$-linked polymers (Johnson, 1965; Bull, 1970; Zonneveld, 1971; Stagg \& Feather, 1973). Cell wall galactomannan from $A$. niger contains $(1 \rightarrow 2)-\alpha-$ and $(1 \rightarrow 6)$ - $\alpha$-linked D-mannopyranosyl units with terminal galactofuranose units as non-reducing end-groups of D-galactopyranosyl side chains (Bardalaye \& Nordin, 1977). This galactomannan corresponds closely with that isolated from A. fumigatus extracts by Azuma et al. (1971), who 
also found a $(1 \rightarrow 4)-\alpha$-linked glucan with $(1 \rightarrow 6)$ - $\alpha$-linked branch points. Enzymes with the ability to hydrolyse these linkages were tested for their effect on surface structures of A. fumigatus. A decrease in binding of IgG to the cell surface was caused by $\alpha$-amylase, $\alpha$-mannosidase and Cytophaga extract, which contains a mixture of relatively non-specific endoglucanases. On the other hand, $\beta$-amylase and exo-( $(\rightarrow 3)$ - $\beta$-glucanase, which act on the non-reducing end-groups of polysaccharide chains, had no significant effect. It is difficult to evaluate the effect of $T$. harzianum culture filtrate, which constitutes a very complicated hydrolytic mixture (de Vries \& Wessels, 1972). However, it is of interest that extra sites are exposed, rather than destroyed, by this treatment.

Whether this alteration in IgG binding is due to a direct enzyme effect on antigenic sites or to a disorganization of the cell surface has not been established. In some cases, e.g. in the action of Cytophaga extract on A. niger and A. terreus, it was apparent from SEM studies that the effects of hydrolysis were widespread and the total surface architecture was damaged. What is clear is that release of $(1 \rightarrow 4)-\alpha-,(1 \rightarrow 3)-\beta$ - and $(1 \rightarrow 4)-\beta$-linked glucose residues, in addition to $(1 \rightarrow 2)-\alpha-$ and/or $(1 \rightarrow 3)-\alpha$-linked mannose units from the mycelial surface, affected IgG binding to antigen sites.

Of the enzymes tested, $\alpha$-amylase had the most widespread effect on surface architecture as measured by reduced antibody binding to the aspergilli. $\beta$-Amylase effected changes in only two species, namely $A$. terreus and $A$. nidulans, the former being the only one not affected by $\alpha$ amylase. Aspergillus flavus appeared singularly unaffected by most enzyme treatments; however, $(1 \rightarrow 3)$ - $\beta$-glucanase caused increased binding and $\alpha$-amylase caused decreased binding of IgG to surface structures. Despite the battery of enzymes present in the culture filtrate of $T$. harzianum, only $\boldsymbol{A}$. terreus in addition to A. fumigatus was affected. While chitin is considered to constitute an underlying layer of hyphal wall material, chitinase was responsible for an increase in antibody binding in the case of $\boldsymbol{A}$. terreus and a decrease in the case of $\boldsymbol{A}$. niger. However, it cannot be ruled out that the low level of $(1 \rightarrow 3)$ - $\beta$-glucanase activity present in the commercial preparation made sites accessible for chitin hydrolysis.

The results obtained provide additional information on the nature of $\boldsymbol{A}$. fumigatus surface structures. As purified and chemically defined moieties are isolated from Aspergillus they may be used to advantage in this system as possible inhibitors to antibody uptake and to produce monospecific antisera for binding assays.

I am indebted to Dr D. W. Dresser (Immunology Department, National Institute for Medical Research, Mill Hill, London) for the protocols used for raising antibodies. The electronmicrographs were kindly prepared by $\mathrm{Mr}$ M. Smith and Mrs E. Wilson. I am grateful to Mr G. Shennan and Miss J. John for excellent technical assistance. My thanks are due to Dr M. Kelemen (Microbiology Department, School of Pharmacy, Brunswick Square, London) for constant advice and encouragement.

This work was supported by a grant from the Medical Research Council.

\section{REFERENCES}

azuma, I., Kimura, H., Hirao, F., Tsubura, E. \& YAMAMURA, Y. (1969). Biochemical and immunological studies on Aspergillus. II. Immunological properties of protein and polysaccharide fractions obtained from Aspergillus fumigatus. Mycopathologia et mycologia applicata 37, 289-303.

azuma, I., Kimura, H., Hirao, F., Tsubura, E., YamamuRa, Y. \& MisaKi, A. (1971). Biochemical and immunological studies on Aspergillus. III. Chemical and immunological properties of glycopeptide obtained from Aspergillus fumigatus. Japanese Journal of Microbiology 15, 237-246.

Ballou, C. (1976). Structure and biosynthesis of the mannan component of the yeast cell envelope. Advances in Microbiology and Physiology 14, 93-158.

Bardalaye, P. C. \& Nordin, J. H. (1977). Chemical structure of the galactomannan from the cell wall of
Aspergillus niger. Journal of Biological Chemistry 252, 2584-2591.

BARTNICKI-GARCIA, S. (1968). Cell wall chemistry, morphogenesis and taxonomy of fungi. Annual Review of Microbiology 22, 87-108.

Biberfeld, P., Biberfeld, G., Molnar, Z. \& FagraeUs, A. (1974). Fixation of cell-bound antibody in the membrane immunofluorescence test. Journal of Immunological Methods 4, 135-148.

Biberfeld, P., Ghetie, V. \& SJöQuist, J. (1975). Demonstration and assaying of IgG antibodies in tissues and on cells by labelled Staphylococcal Protein A. Journal of Immunological Methods 6, 249259.

Bolton, A. E. \& Hunter, W. M. (1973). The labelling of proteins to high specific radioactivities by conjugation to a ${ }^{125}$ I-containing acylating agent. 
Application to the radioimmunoassay. Biochemical Journal 133, 529-539.

Bull, A. T. (1970). Chemical composition of wild-type and mutant Aspergillus nidulans cell walls. The nature of polysaccharide and melanin constituents. Journal of General Microbiology 63, 75-94.

Dorval, G., Welsh, K. I. \& Wigzell, H. (1974). Labelled Staphylococcal Protein A as an immunological probe in the analysis of cell surface markers. Scandinavian Journal of Immunology 3, 405-411.

Dorval, G., Welsh, K. I. \& Wigzell, H. (1975). A radioimmunoassay of cellular surface antigens on living cells using iodinated soluble Protein A from Staphylococcus aureus. Journal of Immunological Methods 7, 237-250.

Harboe, M. \& Fölling, I. (1974). Recognition of two distinct groups of $\operatorname{IgM}$ and $\operatorname{IgA}$ based on differential binding to staphylococci. Scandinavian Journal of Immunology 3, 471-482.

Hearn, V. M. \& Mackenzie, D. W. R. (1979). The preparation and chemical composition of fractions from Aspergillus fumigatus wall and protoplasts possessing antigenic activity. Journal of General Microbiology 112, 35-44.

Hearn, V. M. \& Mackenzie, D. W. R. (1980). Mycelial antigens from two strains of Aspergillus fumigatus: an analysis by two-dimensional immunoelectrophoresis. Mykosen 23, 549-562.

Hearn, V. M., Wilson, E. V. \& Mackenzie, D. W. R. (1980). The preparation of protoplasts from Aspergillus fumigatus mycelium. Sabouraudia 18, 75-77.

Hearn, V. M., Wilson, E. V. \& Mackenzie, D. W. R. (1981). Antigen analysis of Aspergillus fumigatus mycelium. In Proceedings of the VIth International Symposium on Glycoconjugates, p. 381 . Edited by T. Yamakama, T. Osawa \& S. Handa. Tokyo: Japan Scientific Societies Press.

HoRIKOSHI, K. \& ARIMA, K. (1962). X-ray diffraction patterns of the cell wall of Aspergillus oryzae. Biochimica et biophysica acta 57, 392-394.

HunsLey, D. \& BuRNETT, J. H. (1970). The ultrastructural architecture of the walls of some hyphal fungi. Journal of General Microbiology 62, 203-218.

Hunter, W. M. \& Greenwood, F. C. (1962). Preparation of iodine-131 labelled human growth hormone of high specific activity. Nature, London 194, 495-496.

JoHnson, I. R. (1965). The composition of the cell wall of Aspergillus niger. Biochemical Journal 96, 651-658.

Kuo, M.-J. \& AleXander, M. (1967). Inhibition of lysis of fungi by melanins. Journal of Bacteriology 94 , 624-629.

LehmanN, P. F. \& ReIss, E. (1978). Invasive aspergillosis: antiserum for circulating antigen produced after immunization with serum from infected rabbits. Infection and Immunity 20, 570-572.

LLOYD, K. O. (1970). Isolation, characterisation and partial structure of peptidogalactomannans from the yeast form of Cladosporium werneckii. Biochemistry 9 , 3446-3453.

Lloyd, K. O. \& BrToon, M. A. (1971). Isolation and purification of a peptido-rhamnomannan from the yeast form of Sporothrix schenckii. Structural and immunochemical studies. Journal of Immunology 107, 663-671.
Lloyd, K. O., Mendonça-Previato, L. \& Travassos, L. R. (1978). Distribution of antigenic polysaccharides in different cell types of Sporothrix schenckii as studied by immunofluorescent staining with rabbit antisera. Experimental Mycology 2, 130-137.

Odds, F. C., Kaufman, L., Mclaughlin, D., Callaway, C. \& Blumer, S. O. (1974). Effect of chitinase complex on the antigenicity and chemistry of yeast-form cell walls and other fractions of Histoplasma capsulatum and Blastomyces dermatitidis. Sabouraudia 12, 138-149.

Polacheck, Y. \& Rosenberger, R. F. (1975). Autolytic enzymes in hyphae of Aspergillus nidulans: their action on old and newly formed walls. Journal of Bacteriology 121, 332-337.

Potgieter, H. J. \& AleXander, M. (1965). Polysaccharide components of Neurospora crassa hyphal walls. Canadian Journal of Microbiology 11, 122-125.

Previato, J. O., Gorin, P. A. J. \& Travassos, L. R. (1979). Cell wall composition in different cell types of the dimorphic species Sporothrix schenckii. Experimental Mycology 3, 83-91.

Proctor, A. G. (1976). Mycological methods. In Microbiological Methods, 4th edn, pp. 181-193. London: Butterworths.

ReIss, E. (1977). Serial enzymatic hydrolysis of cell walls of two serotypes of yeast-form Histoplasma capsulatum with $\alpha$-( $(1 \rightarrow 3)$-glucanase, $\beta$ - $(1 \rightarrow 3)$-glucanase, pronase and chitinase. Infection and Immunity 16, 181-188.

Righelato, R. C., Trinci, A. P. J., Pirt, S. J. \& Peat, A. (1968). The influence of maintenance energy and growth rate on the metabolic activity, morphology and conidiation of Penicillium chrysogenum. Journal of General Microbiology 50, 399-412.

SaN-BLas, G. (1982). The cell wall of fungal human pathogens: its role in host-parasite relationships. Mycopathologia 79, 159-184.

StaGg, C. M. \& Feather, M. S. (1973). The characterization of a chitin-associated D-glucan from the cell walls of Aspergillus niger. Biochimica et biophysica acta 320, 64-72.

Steinbuch, M. \& Audran, R. (1969). The isolation of IgG from mammalian sera with the aid of caprylic acid. Archives of Biochemistry and Biophysics 134, 279-284.

Stoddart, R. W. \& Herbertson, B. M. (1978). The use of fluorescein-labelled lectins in the detection and identification of fungi pathogenic for man: a preliminary study. Journal of Medical Microbiology 11, 315-324.

Sunayama, H. \& Suzuki, S. (1970). Studies on the antigenic activities of yeasts. V. Effect of $\alpha$ mannosidase digestion on the immunochemical properties of the mannan from Saccharomyces cerevisiae. Japanese Journal of Microbiology 14, 197207.

Travassos, L. R., de Sousa, W., Mendonça-Previato, L. \& LLOYD, K. O. (1977). Location and biochemical nature of surface components reacting with Concanavalin A in different cell types of Sporothrix schenckii. Experimental Mycology 1, 293305.

DE VRIES, O. M. H. \& Wessels, J. G. H. (1972). Release of protoplasts from Schizophyllum commune by a lytic 
enzyme preparation from Trichoderma viride. Journal of General Microbiology 73, 13-22.

WILSON, E. V. \& HEARN, V. M. (1983). Use of Aspergillus fumigatus mycelial antigens in enzymelinked immunosorbent assay and counterimmunoelectrophoresis. Journal of Medical Microbiology 16, 97-105.

Zeltzer, P. M. \& Seeger, R. C. (1977). Microassay using radioiodinated Protein A from Staphylococcus aureus for antibodies bound to cell surface antigens of adherent tumour cells. Journal of Immunological Methods 17, 163-175.

ZoNNEVELD, B. J. M. (1971). Biochemical analysis of the cell wall of Aspergillus nidulans. Biochimica et biophysica acta 249, 506-514. 